\title{
PEMBAJAKAN PRODUK: DILEMA BUDAYA ANTARA BARAT DAN TIMUR KAJIAN LITERATUR PADA SISI PERMINTAAN
}

\author{
Anas Hidayat \\ Ian Phau \\ Fakultas Ekonomi Universitas Islam Indonesia \\ School of Marketing, Curtin University of Technology, Perth, Australia
}

\begin{abstract}
Abstrak
Consumers are the actual force behind the counterfeiting trade. The main problem of the demand side is clearly an issue of consumer misbehaviour. Such behaviour is potentially harmful to business, the consumers themselves, and society as a whole. Astonishingly, Asian people who constitute the majority of the world's population support this activity. Asian people generally have low expectations of branded products, because they tend to blindly believe that foreign brands are best, and they do not distinguish among different brands.

It is possible that most of the Intellectual Property Rights (IPR) infringements taking place in Asian countries may stem from cultural differences in morality and perspective between people in the East and the West. Asian cultures have traditionally emphasized that individual developers or creators are obliged to share their developments with society. IPR, on the other hand, reflects a characteristic value of the Western World in general. Indeed, some Asian nations seem to believe that IPR is a Western concept created to maintain a monopoly over the distribution and production of knowledge and knowledge based products. As a result, when foreign countries on Asian countries to develop laws to counter trademark infringements place pressure, counterfeit products have not diminished.

In relation to the demand for acknowledgment of original works of human intellect and the magnitude of the protection of intellectual property rights, the Indonesian Government has taken a number of considerable measures in establishing and improving the intellectual property rights system, with regards to its worldwide obligations as approved in the Trade-Related Aspects of Intellectual Property Rights (TRIPS) Agreement, as one of the agreements of the World Trade Organisation (WTO). In fact, Intellectual Property Rights (IPR) has become one of the essential means of the global trade.
\end{abstract}

\section{PENDAHULUAN}

Belanja produk bajakan adalah penomena perilaku konsumen yang sudah biasa di Indonesia, tidak ada hal yang aneh apalagi merasa dosa, membeli produk tersebut. Karena sudah biasanya melihat perilaku jual beli produk bajakan, masyarakat seolah-olah telah melejitimasi bahwa bisnis produk bajakan bukan suatu kejahatan ekonomi. Para ahli pemasaran - terutama akademisi- bahkan mengenyampingkan dari objek penelitiannya. Padahal, persoalan pembajakan produk ini telah menjadi isu serius dan menarik bagi peneliti pemasaran dan ilmu lainnya, terutama hukum, mengingat dampak yang di akibatkannya sangat serius, baik ditinjau dari sudut ekonomi maupun dari sudut pemakai produk. Dari kaca mata ekonomi, akan merugikan pemasukan negara melalui pajak, dan akan merugikan pengusaha dari sisi pengahsilan. Sedangkan dari sisi konsumen, membahayakan 
kesehatan dan keselamatan pemakai produk karena mengkonsumsi produk yang sering kali tidak sesuai dengan standard produk aslinya.

Meskipun upaya menghargai kekayaan intelektual ini sudah berumur cukup lama, permasalahan pembajakan tidak semakin menurun tetapi bertambah merajalela sehingga menjadi bisnis besar yang merugikan pihak pemegang merek sebesar milyaran dollar. Misalnya, Amerika Serikat rata-rata pertahun mengalami kerugian dalam bisnis akibat pembajakan sebesar 200 triliun dolar US, dan kalau dilihat dari kerugian dunia akibat bisnis ini rata-rata $15 \%$ dari total penjualannya pertahun (Delener 2000; dan Shultz II \& Saporito 1996).

Lebih memprihatinkan lagi, kawasan Asia merupakan kawasan yang menjadi tertuduh terbesar sumber pembajakan di dunia. Akar masalahnya, menurut McDonald dan Roberts (1994) dan Lai \& Zaickowsky (1999) bahwa kejahatan Hak atas Kekayaan Intelektual (HaKI) di Asia ini sebenarnya merupakan perbedaan cara pandang budaya antara Barat dan Timur. Budaya Asia menekankan pada budaya "sharing" atau saling memberi, sedangkan budaya Barat merupakan masyarakat yang individualistik yang sangat menghargai hak individu. Oleh karena itu, pandangan "Timur" melihat bahwa suatu penemuan oleh seseorang sudah menjadi kewajibannya untuk menyebarkan kepada orang lain dalam rangka pengembangan masyarakat luas. Di sisi lain, HaKI yang melindungi hak individu dianggap merupakan refleksi budaya Barat. Bahkan dipercaya sebagai upaya "Barat" untuk mempertahankan monopoli bisnis dari hilir sampai hulu, serta upaya monopoli pengetahuan yang seharusnya menjadi hak semua umat (Kau, Rinnie \& Swinyard 1990; dan Lai \& Zaickowsky 1999).

\section{TUJUAN PENULISAN PAPER}

Tulisan ini akan menguraikan persoalan pembajakan produk dengan mendasarkan pada kajian-kajian para ahli di dunia, paling tidak dua dasawarsa terakhir ini. Perkembangan terkini yang terkait dengan masalah pembajakan terutama di Indonesia. Di samping itu juga akan melihat peluang-peluang kajian di bidang pemasaran yang berkaitan dengan pembajakan produk di Indonesia. Untuk menguraikan penomena pembajakan produk ini, penulis menggunakan kacamata kontijensi teori dengan asumsi bahwa perilaku bisnis tidak terlepas dari pengaruh lingkungan yang mendukung tumbuhnya bisnis ini. Dengan kata lain bisnis pembajakan kontijen dengan lingkungan bisnis tersebut. Salah satu lingkungan bisnis yang sangat mempengaruhi perilaku bisnis suatu Negara adalah budaya. 


\section{PENGERTIAN PEMBAJAKAN PRODUK}

Pembajakan produk pada dasarnya adalah menggunakan tanpa ijin pemegang merek atau hak atas kekayaan intellectual (intellectual ownership) yang syah. Secara fisik, pembajakan ini merupakan tindakan meniru atau mengkopi produk asli (pemegang merek asli) dan memasarkannya. Biasanya produk yang dikopi merupakan produk-produk terkenal. Pada umumnya yang dikopi adalah pembungkusan dan bahan bakunya yang dibuat sedemikian rupa sehingga menyerupai aslinya (Lynch 2002), termasuk juga didalamnya pemalsuan trademark beserta pelabelannya (Ang et al. 2001; dan Phau et al. 2001).

Dalam perkembangannya masalah pembajakan produk mengalami banyak istilah atau penyebutan. Perkembangan ini mungkin di dukung oleh perkembangan tehnologi yang sangat pesat di dunia, dan tehnologi itu sendiri semakin mudah di akses oleh semua orang. Akibatnya adalah membuat para pembajak melakukan berbagai macam bentuk pemalsuan dengan lebih mudah, dan tidaklah heran bahwa jenis pembajakanpun menjadi semakin beragam.

Keberagaman jenis pembajakan produk pada awalnya ada 4 jenis yang teridentifikasi oleh Lai dan Zaichowsky (1999), yaitu: Counterfeiting, Piracy, Imitation Brand; dan A large "grey" area. Phau, Prendesgast; dan Chuen (2001) menambahkan satu istilah lagi, Custom made copies. Kemudian dalam perkembangan di dunia tehnologi computer muncul istilah tersendiri: softlifting (Khoen \& Im 1997; dan Shore et al. 2001); commercial piracy dan corporate piracy (Koen \& Im 1997); dan perkembangan terakhir muncul istilah baru, garage piracy (Wijk 2002). Penulis kesulitan menterjemahkan istilah-istilah tersebut ke dalam Bahasa Indonesia secara pas. Namun demikian pengertian dari istilah tersebut dalam Bahasa Indonesia dapat di jelaskan pada tabel 1.

Bagaimana dengan Indonesia? Barangkali semua jenis pembajakan di atas dapat kita temui di Indonesia. Ragam pemalsuan mulai dari bertujuan menipu konsumen yang tanpa sadar telah membeli produk palsu-konsumen telah menjadi korban (Grossman \& Shapiro 1988), sampai dengan konsumen yang sadar telah membeli, mengkopi, atau memalsu produk (Chakraborty et al. 1996). ${ }^{1}$ Siapa pembeli produk palsu dengan porsi terbe-

\footnotetext{
1 Pada dasarnya transaksi yang terjadi dalam bisnis pembajakan ada dua, yaitu (Grossman \& Shapiro 1988; dan Chakraborty et al. 1996):

a. Korban produk palsu (deceptive transactional/consumers) yaitu transaksi yang dilakukan oleh konsumen dengan harapan mendapatkan produk asli tetapi kanyataannya produk yang di beli palsu.

b. Pembeli produk palsu (non-deceptive transactional/consumers) yaitu transaksi yang dilakukan oleh konsumen yang sudah mengetahui bahwa produk yang sedang di beli adalah palsu. Pada umumnya alas an membeli produk palsu/imitasi karena perbedaan harga yang sangat signifikan dengan produk aslinya.
} 
sar di dunia? Wee et al. (1996) menyebutkan bahwa konsumen terbesar didunia untuk produk palsu adalah konsumen yang "sadar" membeli produk palsu (non-deceptive consumers).

Tabel 1

Jenis Pembajakan Produk di Dunia

\begin{tabular}{|c|c|c|c|}
\hline No & Nama & Pengertian & Contoh \\
\hline 1 & Counterfeiting & $\begin{array}{l}\text { Pemalsuan produk yang dibuat persis } \\
\text { dengan aslinya (mengkopi } 100 \% \text { ) ber- } \\
\text { tujuan untuk mengelabui yang tidak } \\
\text { sadar bahwa produk itu palsu (Bamossy } \\
1985 \text { dan Lai \& Zaickowsky 1999) }\end{array}$ & $\begin{array}{l}\text { Jam tangan cartier, pemalsuan uang, } \\
\text { dan spare part pesawat terbang }\end{array}$ \\
\hline 2 & Piracy & $\begin{array}{l}\text { Hampir sama dengan counterfeiting } \\
\text { dengan perbedaan pada pembeli yang } \\
\text { sadar bahwa produk yang dibeli adalah } \\
\text { palsu karena ada perbedaan harga } \\
\text { yang signifikan (Wee et al. 1995) }\end{array}$ & $\begin{array}{l}\text { Membeli jam rolex di pinggir jalan } \\
\text { dengan harga sangat murah }\end{array}$ \\
\hline 3 & $\begin{array}{l}\text { Imitation } \\
\text { Brands }\end{array}$ & $\begin{array}{l}\text { Pemalsuan dengan bentuk yang dibe- } \\
\text { dakan sedikit dari produk aslinya, bisa } \\
\text { bungkusnya, label, atau material yang } \\
\text { digunakannya }\end{array}$ & $\begin{array}{l}\text { Jam tangan Cimega untuk mengi- } \\
\text { mitasi Omega; ikat pinggan Danihilm } \\
\text { Dunhill }\end{array}$ \\
\hline 4 & Grey area & $\begin{array}{l}\text { Pabrikan pemegang merk asli mem- } \\
\text { produksi dari yang seharusnya dibu- } \\
\text { tuhkan tanpa dipasang label aslinya dan } \\
\text { dijual secara illegal }\end{array}$ & $\begin{array}{l}\text { Penjualan produk tanpa merk dari } \\
\text { perusahaan pemegang merk tsb. } \\
\text { Misalnya sparepart motor Honda asli } \\
\text { tapi tanpa merk }\end{array}$ \\
\hline 5 & $\begin{array}{l}\text { Custom-Made } \\
\text { Copies }\end{array}$ & $\begin{array}{l}\text { Meniru produk aslinya dengan cara } \\
\text { meminta tolong kepada pengrajin, } \\
\text { biasanya merknya tidak ada tetapi } \\
\text { produknya bisa sama persis dengan } \\
\text { aslinya karena menggunakan bahan } \\
\text { yang berkualitas }\end{array}$ & $\begin{array}{l}\text { Meniru sepatu adidas melalui tukang } \\
\text { sepatu }\end{array}$ \\
\hline 6 & Shoft-lifting & Mengkopi software tanpa ijin & $\begin{array}{l}\text { Sesorang mengkopy software dari } \\
\text { temannya }\end{array}$ \\
\hline 7 & $\begin{array}{l}\text { Commercial } \\
\text { piracy }\end{array}$ & $\begin{array}{l}\text { Mengkopi software dengan tujuan } \\
\text { dijual kembali }\end{array}$ & $\begin{array}{l}\text { Seseorang membeli software asli sat } \\
\text { uterus dikopi sebanyak mungkin } \\
\text { untuk dijual kepada pihak ketiga }\end{array}$ \\
\hline 8 & $\begin{array}{l}\text { Corporate } \\
\text { piracy }\end{array}$ & $\begin{array}{l}\text { Mengkopi software untuk kepentingan } \\
\text { kantor }\end{array}$ & $\begin{array}{l}\text { Sebuah kantor membeli satu asli } \\
\text { software terus diperbanyak untuk } \\
\text { kepentingan kantor tersebut }\end{array}$ \\
\hline 9 & Garage piracy & $\begin{array}{l}\text { Mengkopi software atau music dalam } \\
\text { skala kecil melalui media internet }\end{array}$ & $\begin{array}{l}\text { Seseorang endonlod lagu-lagu di- } \\
\text { internet tanpa ijin dengan cara me- } \\
\text { rusak password }\end{array}$ \\
\hline
\end{tabular}




\section{DAMPAK PEMBAJAKAN PRODUK DAN KESADARAN KONSUMEN}

Dampak kerugian akibat pembajakan sebenarnya berdimensi banyak, tidak hanya persoalan kerugian bisnis semata tetapi juga kerugian ekonomi Negara dan bahkan pada konflik antar Negara bisa juga terjadi (IACC 2002; dan McDonald dan Roberts 1994). Sebagai ilustrasi, berikut adalah contoh kerugian yang di timbulkan (lihat tabel 2):

Tabel 2

Dampak dan Kerugian Akibat pemabajakan

\begin{tabular}{|c|c|c|}
\hline No & Dampak Ke & Jenis Kerugian \\
\hline 1 & $\begin{array}{l}\text { Pelaku Bis- } \\
\text { nis }\end{array}$ & $\begin{array}{l}\text { - Pembajakan produk telah mengakibatkan menurunnya reputasi sebuah merk } \\
\text { atau brand (Delener 2000); } \\
\text { - Biaya riset dan pengembangan yang telah dikeluarkan menjadi tidak memberikan } \\
\text { nilai tambah dan biaya untuk urusan legal formal menjadi membesar (Nash 1989); } \\
\text { - Menurunkan laba dari perusahaan pemegang merk atau brand yang sah } \\
\text { (Block, Bush \& Campbell 1993); } \\
\text { - Pada tahun } 1994 \text { industri software USA mengalami kerugian US } \$ 8.08 \\
\text { milyard karena tindakan mengkopi tanpa ijin oleh banyak konsumen dan pe- } \\
\text { laku bisnis lainnya (Gabella \& Picasso 1995); and } \\
\text { - Perusahaan peralatan dan pakaian ski Korea Selatan diperkirakan mengalami } \\
\text { kerugian US \$1 juta pertahun karena ulah pembajak (IACC 2002) }\end{array}$ \\
\hline 2 & Konsumen & $\begin{array}{l}\text { - Obat-obatan palsu atau obat yang tidak dikemas sesuai dengan dosis } \\
\text { seharusnya; suku cadang otomotif dan kapal terbang yang dipalsukan/tidak } \\
\text { orisinil akan membahayakan jiwa konsumen, kopi palsu yang di campur de- } \\
\text { ngan batu terjadi di Rumania telah memberi dampak yang sangat berbahaya } \\
\text { terhadap keselamatan dan kesehatan konsumen (Wee, Tan \& Cheok 1995; } \\
\text { Bush et al 1989; Crandall 1986; Harvey \& Ronkainen 1985; Harvey 1988; } \\
\text { and Shultz II \& Saporito 1996); } \\
\text { - Pembajakan yang semakin canggih yang dibantu oleh perkembangan tehnologi } \\
\text { telah membingungkan konsumen dalam membedakan produk asli dengan produk } \\
\text { palsu (Bush et al 1989; Olsen \& Granzin 1992: Michael \& Papavassiliou } \\
\text { 1997; Nash 1989; Wilkie \& Ziachkowsky, 1999; and Delener 2000). }\end{array}$ \\
\hline 3 & $\begin{array}{l}\text { Negara dan } \\
\text { masyarakat }\end{array}$ & $\begin{array}{l}\text { - Kenya, Zaire, dan Vietnam mengalami kerugian jutaan dollar kerena kerusakan } \\
\text { hasil pertanian akibat pemalsuan pupuk dan pestisida (Bush et al 1989); } \\
\text { - Pada tahun } 1994 \text { kota New York kehilanagn pendapatan pajak akibat perda- } \\
\text { gangan produk bajakan sebesar US \$ } 350 \text { juta (IACC 2002); } \\
\text { - Dunia bisnis USA mengalami kerugian sebesar US \$ } 200 \text { milyar karena } \\
\text { pembajakan produk setiap tahun (Delener } 2000 \text { and Shultz II \& Saporito 1996), } \\
\text { bandingkan dengan kerugian yang terjadi pada tahun } 1986 \text { sebesar US \$ } 61 \\
\text { milyard. Sebuah lonjakan yang sangat besar (Shultz II and Saporito 1996); and } \\
\text { - Amerika Serikat mengancam Thailand untuk mengurangi bantuan ekonominya } \\
\text { karena berkaitan dengan pembajakan produk yang merajalela di negara } \\
\text { tersebut (McDonald \& Roberts 1994). }\end{array}$ \\
\hline
\end{tabular}

Sumber: Phau \& Prendesgast 1998; dan Hidayat \& Phau 2003b 
Hampir tidak ada produk terkenal di dunia yang bebas dari resiko pembajakan (Johnson 2001/1002). Berdasarkan penelitian, produk dengan reputasi dunia akan mudah di jual ke masyarakat. Hal ini, mengingat sebagian - barangkali sebagian besar- masyarakat dengan penghasilan menengah bawah ingin juga memiliki produk yang bermerek terkenal meskipun palsu. Disamping itu ada gejala bahwa motif membeli juga di dukung oleh referensi dari keluarga dan teman dengan memberikan apresiasi positif terhadap produk palsu (Bloch et al. 1993; dan Phau et al. 2000).

Harvey (1988) manambahkan bahwa saat ini produk palsu nampaknya semakin mendapat apresiasi dari konsumen, hampir tidak ada perbedaan yang signifikan antara persepsi produk yang asli dengan yang palsu di benak konsumen. Konsekuensinya adalah produk bajakan menyebar seperti jamur di musim hujan, sehingga menjadi fenomena dunia (Chaudhry \& Walsh 1996; Schultz II \& Saporito 1996; dan Benghozi \& Santagata 1998). Karenanya, konsumen semakin tidak sadar bahwa produk bajakan tersebut merupakan hasil dari aktifitas kejahatan bisnis karena memandangnya sebagai produk yang memiliki ciri khas sendiri dengan identitas sendiri. Dengan kata lain, seolah-olah, produk bajakan tersebut merupakan produk dengan merek sendiri.

\section{PEMBAJAKAN PRODUK DI ASIA}

Suburnya permintaan produk palsu, berdasarkan penelitian, menunjukkan bahwa factor permintaan menjadi penyebab utama tumbuh pesatnya bisnis ini (Chan, Wong \& Leung 1998). Apabila dikaji lebih dalam, nampaknya perilaku konsumen yang menyimpang atau perilaku yang tidak beretika menjadi unsur utama mengapa konsumen ingin membeli produk palsu tersebut (Miller 1999). Seperti di sebutkan di atas, porsi terbesar pembeli produk bajakan ini adalah konsumen yang "sadar membeli" (nondeceptive consumers). Konsumen dengan kategori 'non-deceptive' terbesar berada di Asia karena memang porsi penduduknya yang paling besar di dunia. Lebih dari pada itu, tumbuh suburnya konsumen dengan golongan 'non-deceptive' di Asia karena ditunjang juga oleh budaya Asia yang percaya secara membabi buta terhadap produk luar negeri terutama produk "Barat". Di samping itu, konsumen Asia memang tidak begitu memperhatikan masalah-masalah yang berkaitan terhadap arti pentingnya merek karena latar belakang pendidikan mereka yang rendah (Lai \& Zaickowsky 1999).

Berdasarkan "The US Representative's 1998 Special 301", negara-negara Asia Timur termasuk di dalamnya Indonesia, Macao, Hong Kong, Japan, Korea, Pilipina, Singapore, Thailand, dan Vietnam meru- 
pakan Negara yang termasuk dalam daftar yang tidak mengikuti secara ketat perlindungan atas kekayaan intelektual dan dituduh melakukan bisnis tidak adil terhadap USA. Pernyataan ini barangkali karena melihat bahwa penyalahgunaan hak atas kekayaan intelektual sangat subur di kawasan ini (East Asian Executive Reports 1998). Bahkan Johnson (2001/2002) mengatakan bahwa tidak ada produk yang terkenal didunia tidak dipalsu dikawasan negara-negara di atas. Semua produk terkenal yang palsu dapat dengan mudah diperoleh oleh konsumen.

Nampaknya secara bisnis, motif utama pembajakan produk adalah uang. Keuntungan dari pembajakan produk memang sangat menjanjikan, sehingga pada satu dasa warsa yang lalu ada tuduhan untuk negara-negara berkembang bahwa pembajakan produk ini menjadi salah satu strategi nasional yang dilegalkan oleh suatu Negara (Paula 1986; dan Harvey 1988). Selain itu, sebagian masyarakat percaya bahwa pembajakan produk sepertinya merupakan kejahatan melalui pengambilan hak orang kaya oleh orang miskin (Wada 1996), maka seolah-olah perbuatan menggandakan produk resmi tanpa ijin merupakan bisnis yang tidak melanggar hukum. Apalagi memang belum ada kesamaan definisi dalam membrantas pembajakan produk ini, sehingga belum ada peraturan yang keras dapat menjerat secara efektif pelaku kejahatan pemalsuan produk (Johnson 2001/2002).

Disamping itu, Lingkungan bisnis juga tidak bisa lepas dari perhatian para ahli untuk mengantisipasi bisnis illegal ini. Misalnya, kesungguhan aparat dalam menegakkan hukum (Simone 1999; dan Shultz II \& Saporito 1996), ketidakpastian politik yang menyebabkan ketidakpastian berbisnis secara normal (Lai \& Zaickowsky 1999); dan kerja sama internasional dikawasan Asia memang belum kuat dalam memonitor produk-produk illegal tersebut (Harvey 1988). Karenanya, usaha membrantas pembajakan produk masih melalui jalan yang sangat panjang, terutama di kawasan Asia.

Namun demikian, dari beberapa penelitian terbaru menyebutkan bahwa pelaksanaan perlindungan hak atas kekayaan intelektual sudah semakin baik. Strategi melindungi dengan metode khusus nampaknya telah menumbuhkan hasil. Hal ini terbukti dengan semakin membesarnya biaya produksi untuk pemalsuan produk. Saat ini pemalsu harus merogoh kantong semakin dalam untuk biaya inovasi sebagai upaya menghindari jerat hukum. Sebagai ilustrasi, di bandingkan dengan biaya produksi produk aslinya, biaya produksi produk bajakan rata-rata sudah mencapai $65 \%$, dan hanya sedikit yang mengeluarkan biaya produksi $20 \%$ saja (Glass \& Saggi 2002). Karenanya, Lai \& Qiu (2003) mengatakan perkembangan positip ini merupakan sesuatu yang semakin menyulitkan bisnis illegal dan semakin mengarah kepada bisnis yang kurang menguntungkan. 
Pernyataan di atas mungkin ada benarnya, karena dari perkembangan terkini, negara di kawasan Asia sudah mulai mengundangkan perlindungan HaKI sebagai bentuk keseriusan mereka untuk menghormati "knowledge ownership" ini. Apalagi langkah ini menjadi sebuah kewajiban ketika dikaitkan dengan kerangka kerjasama perdagangan internasional antara Barat dan Timur. Misalnya China atas desakan Amerika membuat badan yang disebut "QBPC" atau the Quality Brand Protection Committee (Johnson 2001/2002). Meskipun mundur satu tahun setelah diundangkan, Indonesia pada tanggal 29 Juli 2003 juga telah memberlakukan Undang Undang No. 19 Tahun 2002 tentang Hak Cipta sebagai konsekuensi logis menjadi anggota World Trade Organization (WTO).

Namun demikian, apabila dikaitkan dengan budaya yang berkembang di Asia, berdasarkan kajian Wilkie dan Zaickhowsky (1999), persoalan bisnis pembajakan produk dikawasan ini sulit diberantas karena budaya mereka yang seolah-olah melejitimasi usaha ini. Indikasi yang muncul, undang-undang pembajakan yang sedang sibuk di tegakkan, justru bukan menjadi sesuatu yang menurunkan semangat pembajakan, tetapi memberikan ide untuk memunculkan strategi lain guna menghindari perangkap legalitas yang ada.

\section{PERGESERAN ALASAN SISI PERMINTAAN}

Produk bermerek atau branding produk paling tidak sudah teridentifikasi sejak jaman Romawi ketika ditemukan dalam tutup botol anggur dengan nama "Amphoras" (Abalos 1985). Pada dasarnya menciptakan merek atau brand adalah untuk menciptakan identitas sebuah produk dengan harapan membangun loyalitas konsumen terhadap produk tersebut. Karenanya produk dan merek harus didaftarkan sebagai upaya untuk melindungi hak atas kekayaan intelektual produk tersebut. Namun kenyataannya adalah semakin terkenal sebuah produk, upaya-upaya untuk meniru produk tersebut oleh pihak lain akan muncul ke permukaan, maka tidaklah heran jika dipasar muncul produk-produk yang tidak berkualitas. Akibatnya adalah merugikan konsumen (Harvey 1988; dan Pinkerton 1990) dan menurunkan reputasi pemegang hak produk asli tersebut (Cordel et al. 1996). Demikian juga secara tidak langsung akan merugikan masyarakat karena kepercayaan akan hilang. Pada gilirannya memunculkan kecurigaan antar konsumen, penjual, dan produsen (Stotland 1977).

Dari hasil kajian empiris, ternyata alasan permintaan terhadap produk bajakan bergeser dari waktu ke waktu. Pergeseran motif pembelian ini di mulai dari membeli produk bajakan karena keterbatasan finansial, kemudian bergeser menuju arah pandangan yang lebih positip terhadap produk bajakan. Artinya bahwa pembeli produk bajakan bukan monopoli 
konsumen dengan kemampuan finansial yang lemah, tetapi telah bergeser kepada konsumen yang lebih luas lagi, dimana konsumen dengan kemampuan finansial kuat juga ikut membeli. Dengan demikian, nampaknya bahwa kampanye pembrantasan pembajakan yang melibatkan konsumen untuk menjauhi produk palsu ini semakin sulit terwujud karena pergeseran pandangan yang positip terhadap produk palsu tersebut. Berikut ini adalah hasil penelitian yang telah dilakukan para ahli (lihat tabel 3)

\section{Tabel 3}

Pergeseran Motif Pembelian Terhadap Produk Bajakan

\begin{tabular}{|l|l|l|}
\hline No & \multicolumn{1}{|c|}{ Peneliti } & \multicolumn{1}{c|}{ Hasil kajian } \\
\hline 1 & Bloch et al. (1993) & Alasan membeli produk palsu karena kondisi keuangan yang minim \\
\hline 2 & Cordel et al. (1996) & $\begin{array}{l}\text { Permintaan akan produk "haram" ini dilandasi oleh performa pro- } \\
\text { duk palsu sudah sesuai dengan harapan konsumen, tidak jauh } \\
\text { dari aslinya }\end{array}$ \\
\hline 3 & Nia \& Zaickowsky (2000) & $\begin{array}{l}\text { Konsumen semakin bersikap positif terhadap produk palsu dengan } \\
\text { indikasi bahwa produk palsu itu tidak merugikan produk aslinya } \\
\text { karena produk palsu posisinya bersifat inferior terhadap produk } \\
\text { asli. }\end{array}$ \\
\hline 4 & $\begin{array}{l}\text { Phau, Prendesgast, dan } \\
\text { Cheung (2001) dan Field } \\
\text { (2000) }\end{array}$ & $\begin{array}{l}\text { Pembelian produk palsu ternyata didukung oleh referensi dari } \\
\text { keluarga, teman, kenyataan produk tersebut yang semakin } \\
\text { berkualitas }\end{array}$ \\
\hline 5 & D'Astous dan Gargouri & $\begin{array}{l}\text { Konsumen tidak memperdulikan masalah kualitas lagi pada pro- } \\
\text { duk imitasi ini, tetapi melihat reputasi penjualnya atau took yang } \\
\text { menjaul produk tersebut. Semakin terpercaya penjualnya semakin } \\
\text { positip dampak penjualan produk palsu tersebut karena penjual } \\
\text { diharapkan memberikan informasi yang jujur }\end{array}$ \\
\hline
\end{tabular}

Pada dasarnya penelitian terhadap konsumen yang dikaitkan dengan permintaan produk palsu akan sangat komplek karena banyak variabel yang dapat dipertimbangkan. Misalnya variabel yang menyangkut karakteristik konsumen seperti etika konsumen atau moralitas konsumen, integritas konsumen, pemenuhan kebutuhan konsumen dan sebagainya. Disamping itu, para ahli juga menyadari bahwa pengaruh lingkungan juga sangat kuat, misalnya kebijakan publik yang tidak konsisten; ketidaksungguhan penegakan hukum dan aturan; ketidakpastian politik dan ekonomi yang transparan dan sebagainya (Lai \& Zaickowsky 1999). Namun demikian, paling tidak penelitian pada sisi permintaan untuk pembajakan produk diarahkan dalam upaya untuk menjawab siapa yang membeli, mengapa membeli, bagaimana membelinya, kapan membelinya, dan dimana membelinya (Wee et al 1996).

Menghentikan laju permintaan pada produk bajakan nampaknya masih jauh dari harapan, terutama untuk konsumen di kawasan Asia yang 
dipicu dengan masih rendahnya kesadaran publik terhadap makna kekayaan intelektual (Fereshti N.D. 2003). Bagi Indonesia, dengan diberlakukannnya Undang-Undang no. 19 tahun 2002 tentang Hak Cipta, paling tidak memebuktikan bahwa pemerintah Indonesia telah menunjukkan keseriusannya dalam membrantas perdagangan produk bajakan. Namun demikian, pada sisi lain, konsumen masih tetap mejadi kendala dengan komitmennya yang rendah terhadap pembrantasan produk bajakan, demikian kata Menteri Kehakiman dan HAM RI (Jawa Pos 2003). Apalagi bahwa mengkonsumsi produk bajakan bukan merupakan tindakan kriminal (Cordell, Wongtada dan Kieschnik 1996). Sehingga masih diperlukan cara untuk menyadarkan konsumen bahwa perbuatan membeli sudah merupakan suatu bentuk dukungan terhadap penjualan produk bajakan.

\section{PROBLEM PELAKSANAAN HAK ATAS KEKAYAAN INTELEKTUAL}

Menurut Steidlmeier (1993) dan Husted (2000), properti atau kekayaan dapat diartikan sebagai hak yang dimiliki dari seseorang atau kumpulan orang (people) yang dapat digunakan sebagai sumber komersialisasi dalam waktu yang lama. Hak ini meliputi kekuasaan untuk menggunakannya dan menghasilkan pendapatan atau income hasil transaksi atau pertukaran kekayaan tersebut. Hak atas Kekayaan Intelektual (HaKI) merupakan hasil dari kegiatan atau aktifitas intelektual seseorang atau kelompok orang di lapangan indusri, keilmuan, literasi, dan seni (Forestor dam Morison 1990). Annex C. Agreement Establishing the World Trade Organisation (pasal 1 ayat 2) menyebutkan bahwa komponen Hak atas Kekayaan Intektual (HaKI) meliputi: Hak Cipta, Merek Dagang, Paten, Desain Produk Industri, Indikasi Geograpi, Desian Tata Letak, Sirkuit Terpadu, dan Perlindungan Informasi yang Dirahasiakan (Bappeda DKI 2003). Upaya memproteksi Hak atas Kekayaan Intelektual terjadi ketika Negara melihat ada kegiatan eksploitasi tanpa hak atas kekayaan intelektual milik orang lain dalam waktu yang di tetapkan (Seyoum 1996; dan Harvey \& Lucas 1996).

Menyimak dari sejarah, proteksi terhadap kekayaan intelektual telah dilaksanakan oleh bangsa Inggris dengan mengundangkannya pelarangan terhadap pembajakan pada tahun 1352 (Steidlmeier 1993). Pada saat itu, Raja Inggris memiliki hak istimewa dengan menguasai semua karya intelektual yang dihasilkan oleh negari-negeri jajahannya (Lantu dan Farida 2003). Kemudian Amerika Serikat dalam konstitusinya pada artikel 1 memberi wewenang kepada pemerintah federal untuk melindungi hak cipta penulis dan penemu selama 100 tahun (Nimmer 1992). Diteruskan pada tahun 1790, Amerika mengundangkan paten (Lehman 1997), dan 
mengundangkan trademark setelah 80 tahun undang-undang paten berjalan, tepatnya 1870 (Harvey \& Lucas 1996).

Pembajakan produk memiliki sejarah yang panjang, dan pembajakan yang paling awal terjadi masuk di area pembajakan buku atau barang cetakan sejak ditemukannya mesin cetak pada akhir tahun 1400 an (Paradise 1999). Pelanggaran undang-undang hak paten mulai di sidangkan di pengadilan Amerika Serikat pada awal tahun 1800an (Dodd \& Zaickowsky 1999). Pada masa bisnis modern, tahun 1970-an pembajakan mulai terasa bergerak pesat oleh pelaku bisnis resmi. Korban terbesar dalam pembajakan dialami oleh Amerika Serikat karena produknya sangat laku di pasaran dunia. Amerika Serikat merupakan negara pemegang merek paling banyak dalam kategori merek teratas dunia seperti disebut dalam "The Top hundred Global Brands" (lihat tabel 4, cuplikan untuk sepuluh merek teratas dunia).

Sebagai contoh, Menurut laporan International AntiCounterfeiting Coalition (IACC) yang anggotanya sudah lebih dari 300 perusahaan besar dunia, dengan kedudukan di Washington DC, menyebutkan bahwa akibat pembajakan produk Amerika Serikat mengalami kerugian ekonomi sebesar 200 billion dollar pada tahun 1995, dan pada tahun yang sama Masyarakat Ekonomi Eropah mengalami kerugian 135 billion dollar (Paradise 1999). Banyaknya pelanggaran Hak Atas Kekakayaan Intelektual (HaKI) akibat pendidikan pelaku bisnis yang masih rendah dan sosialisasi yang rendah terhadap HaKI terutama dikawasan Asia (Wilkie \& Zaickowsky 1999; dan Paradise 1999).

Tabel 3

Sepuluh Merek Teratas Dunia Tahun 2003

\begin{tabular}{|l|l|c|l|}
\hline Ranking & \multicolumn{1}{|c|}{ Merk } & Nilai Merk (\$billion) & \multicolumn{1}{|c|}{ Negara Asal } \\
\hline 1 & Coca-Cola & 70.45 & USA \\
\hline 2 & Microsoft & 65.17 & USA \\
\hline 3 & IBM & 51.77 & USA \\
\hline 4 & GE & 42.34 & USA \\
\hline 5 & Intel & 31.11 & USA \\
\hline 6 & Nokia & 29.44 & FINLAND \\
\hline 7 & Disney & 28.04 & USA \\
\hline 8 & McDonald's & 24.70 & USA \\
\hline 9 & Marlboro & 22.18 & USA \\
\hline 10 & Mercedes & 21.37 & GERMANY \\
\hline
\end{tabular}

Sumber: Business Week (2003)

Ada beberapa tipe proteksi dalam kaitannya dengan HaKI yang meliputi: patents, copyrights, trademarks, trade secrets, design protection, plant variety protection dan lain-lain. Dalam kaitannya dengan kejahatan 
yang bersifat komersial, biasanya pelanggaran yang terjadi meliputi tiga area, yaitu : patents, copyrights dan trademarks. ${ }^{2}$ Banyak tipe pembajakan produk telah dilakukan, dan tipe yang terbesar adalah pelanggaran copyrights (Paradise 1999).

Lemahnya global proteksi tentang HaKI ini memang telah menyebabkan kemunduran bahkan kebangkrutan beberapa industri (Harvey \& Ronkainen 1985; Chaudhry \& Walsh 1995; dan Delener 2000). Macam produk yang dibajak juga sangat bervariasi, mulai dari kebutuhan produk sehari-hari sampai dengan produk teknologi. Kerugian industri Amerika Serikat akibat pelanggaran copyrights adalah $50 \%$ nya berasal dari kawasan Timur Jauh termasuk di dalamnya Asia,dan $25 \%$ dari daerah New York, dan sisanya dari beberapa Negara sekitarnya (Delener 2000, McDonald \& Robert 1994; dan Globerman 1988). Negara Asia dengan penduduk yang terbesar di dunia, seperti China, India, Asia Tenggara dsbnya merupakan problem yang serius untuk bisnis bajakan karena sulitnya mengatasi bisnis ini yang bukan sekedar masalah perolehan keuntungan pelaku bisnis tetapi masuk kemasalah yang komplek termasuk di dalamnya budaya, hukum , politik, dan ekonomi.

Namun demikian, permasalahan yang terbesar yang perlu mendapat perhatian serius adalah perbedaan budaya dalam memandang produk bajakan. Model pendidikan yang berbeda dengan barat dan nilai-nilai Timur yang dijunjung tinggi menjadi kendala dalam penerapan HaKI yang baik. Cara yang paling memungkinkan untuk mendekatkan perbedaan berpikir tersebut adalah pendidikan (Ang et al 2001).

\section{PEMBAJAKAN DALAM PERSPEKTIF BUDAYA}

Nilai-nilai budaya masyarakat nampaknya memiliki dampak yang signifikan terhadap permasalahan tumbuh suburnya usaha pembajakan produk di suatu negara. Pada dasarnya budaya merupakan konsep yang sangat luas, karena budaya dapat mencakup aspek ekonomi, politik, struktur sosial, agama, pendidikan dan bahasa (Chang 2003). Budaya da-

\footnotetext{
${ }^{2}$ Menurut Undang-Undang Amerika Serikat (US Code, Chapter 22) ketiga proteksi tersebut didefinisikan sebagai berikut (Paradise 1999):

a. Trademarks: A word, design, symbol, device, or combination used by a manufacturer or merchant to identify his good and distinguish them from others. For instances: brand names identifying goods and service marks identifying service.

b. Copyrights: An original work of authorship that meet the criteria of originality, tangible form, and fixation. Copyright goes to the form of expression rather than to the subject matter of the writing. For instance: literary works, musical work, dramatic work, etc.

c. Patents: A grant of a property right by the government to the inventor of an original invention that meets the criteria of novelty, unobviousness, and utility. Three types of patents are recognised: utility patent, design patent, and plant patent.

Dalam konsepsi perundangan di Indonesia dapat di lihat di tabel 6 .
} 
pat definisikan sebagai pola pemikiran kolektif dari sekelompok orang/masyarakat yang membedakannya dengan masyarakat yang lain (Hofstede 1997). Pada dimensi yang lebih sempit, pembahasan tentang "nilai-nilai budaya" akan dikaitkan dengan perilaku masyarakat dalam kehidupan sehari-hari. Adapun pengertian "Nilai" sendiri dapat diartikan sebagai suatu gambaran - baik implisit maupun ekplisit- khusus dari individu atau kelompok individu tentang karakter mereka yang menonjol dalam mempengaruhi pola pikir, cara bertindak dan hasil akhir yang diinginkan oleh masyarakat tersebut (Husted 2000). Dengan demikian maka nilai-nilai budaya dapat di artikan sebagai suatu gambaran dari karakter suatu masyarakat. "Perilaku pembajakan produk" merupakan salah satu bentuk karakter yang termasuk dalam definisi di atas.

Maka tidaklah heran kalau Marron \& Steel (2000) mengatakan bahwa konsep HaKI pada dasarnya adalah penomena budaya dan ekonomi, sehingga implikasi HaKI dapat dilihat melalui perspektif budaya dan ekonomi3. Di lihat dari perspektif budaya, unsur budaya konsumen sangat berpengaruh dalam tingkat keberhasilan pelaksanaan HaKI. Hal ini dapat dijelaskan melalui kacamata "Hofstede's Cultural Dimension" dalam kaitannya dengan "individualism-collectivism dimensions". ${ }^{4}$

${ }^{3}$ Tulisan paper ini ditekankan pada pembahasan perspektif budaya. Namun sepertinya tidak lengkap apabila aspek ekonomi tidak di bahas. Oleh karena itu, penulis akan membahasnya sebagai catatan kaki dengan cara yang singkat sbb:

Dari sudut perspektif ekonomi modern, sejak Adam Smith meluncurkan bukunya "The Wealth of Nations" in 1776, konsep kompetisi memegang peranan penting di dunia "Barat", karena pasar yang tidak kompetitif akan menyebabkan tingginya harga dan distribusi sumber daya yang tidak adil. Namun demikian, perusahaan-perusahaan yang memiliki produk kuat di pasar akan sangat cepat di tiru oleh pesaingnya sehingga harga menajdi sangat bersaing dan menciptakan pasar yang sangat efisien.

Kenapa demikian? Secara teoritis, tindakan pembajakan produk merupakan mentransfer informasi untuk melakukan inovasi, dan tindakan ini tidak memerlukan biaya. Kenyataan di lapangan, para pembajak tidak mengeluarkan sepersenpun dana investasi untuk riset dan pengembangan. Sehingga para pembajak akan dapat memproduksi produk tiruannya lebih efisien di bandingkan pabrikan aslinya. Bahkan para pembajak atau peniru dapat mengembangkan lebih lanjut produk yang ditiru dan lebih bagus dari aslinya sehingga konsumen diuntungkan dengan produk yang dibutuhkan karena meningkat mutunya dengan harga yang lebih rendah dan kompetitif (Glass \& Saggi 2002; dan Coriat \& Orsi 2002). Karenanya, jika kompetisi dapat dipandang sebagai bagian yang sangat penting untuk sebuah pasar yang sehat, maka pembajakan produk dapat pula dilihat sebagai upaya mengefisienkan pasar karena alokasi sumber daya dapat terdistribusi secara efisien kepada banyak perusahaan, dan produk yang dibutuhkan oleh konsumen ditawarkan oleh banyak pabrikan/perusahaan (Wilkie \& Zaickowsky 1999).

4 "Hofstede's (1980) individualism-collectivism dimension" membedakan kedua dikotomi tersebut sebagai berikut (Ewing, Napoli \& Caruana 2000; dan Triandis 1995):

a. Paham individualisme adalah masyarakat yang memiliki kepercayaan mengutamakan tujuan individual di atas tujuan bersama dan keyakinan, nilai-nilai dan sikap individu mengendalikan perilaku sosialnya.

b. Paham kolektifisme adalah mengutamakan masyarakat yang memiliki kepercayaan mengutamakan kepentingan bersama di atas kepentingan individual dan dikendalikan oleh normanorma yang berlaku di masyarakat.

Contoh negara yang memiliki masyarakat yang individualistik adalah Amerika, Australia dan Eropah Barat, sedangkan Negara-negara Timur nampaknya mengikuti paham kolektifisme, seperti: Asia, Eropah Timur, Amerika Latin (Hofstede 1980; dan Shkodriani \& Gibbon 1995). 
Negara-negara "Timur" yang dikenal memiliki budaya kolektifisme sangat menekankan pada mendahulukan kepentingan bersama dari pada kepentingan individu. Di pihak lain, Negara-negara "Barat" memiliki budaya individualisme yang menekankan bahwa kepentingan individu harus dihormati, sehingga secara natural budaya "Barat" ini memang sesuai dengan penegakan HaKI yang membutuhkan dukungan pelaku bisnis yang respek pada kepemilikan individual, termasuk di dalamnya kepemilikan intelektual.

Budaya "Timur" yang sangat berbeda konsep dengan budaya "Barat", Membuat masyarakat "Timur" sangat sulit memahami, apalagi mengadopsi budaya lain. Konsep HaKI yang berlandaskan pada filosopi "Barat" justru dipandang lain oleh banyak kalangan "Timur" sebagai usaha "Barat" untuk memonopoli tehnologi dan pengetahuan. Kalangan "Timur" melihat bahwa penemuan pengetahuan oleh seseorang sudah menjadi kewajibannya untuk disebarkan ke masyarakat luas untuk kemaslahatan bersama (Kau, Rinnie \& Swinyard 1990; dan Lai \& Zaickowsky 1999). Sebaliknya pihak "Barat" menekankan pelaksanaan HaKI untuk mendorong penemuan dan inovasi dalam upaya pertumbuhan ekonomi (Marron \& Steel 2000; dan Rapp \& Rozek 1990), dan mendorong kreatifitas seseorang dalam berkarya (Steidlmeier 1993; Ganguli 2000; dan Shore et al. 2001).

Budaya "Timur" yang berlandaskan jiwa kebersamaan menyebabkan suburnya pembajakan produk mengingat produk yang dibajak tersebut memberikan peluang yang besar kepada kepentingan masyarakat untuk memilikinya dan sekaligus membantu pertumbuhan ekonomi. Sebaliknya, budaya "Barat" yang respek pada individualisme sangat menjunjung tinggi hak kepemilikan seseorang sehingga pelaksanaan HaKI jauh lebih berhasil dibandingkan "Timur", dan pembajakan produk yang terjadi di dunia "Barat" kalaupun ada, maka porsinya akan sangat sedikit dibandingkan "timur".

Budaya "Timur" yang seolah-olah "merestui" pembajakan produk, pada dasarnya juga didukung oleh budaya paternalistik melalui pendidikan. Budaya mendidik yang sangat paternalistik lebih banyak menekankan contoh-contoh untuk ditiru oleh anak didik. budaya meniru bagi masyarakat Asia sudah sejak nenek moyang kalau di lihat dari perjalanan sejarah Asia sehingga masuk ke dalam sistem nilai masyarakat Asia. Artinya bahwa tindakan mengkopi atau meniru adalah suatu hal yang biasa bagi masyarakat Asia.

Di tambah lagi, kebanyakan pelaku pembajakan Asia adalah orang-orang ulet yang secara alamiah berjiwa wiraswasta, bukan masyarakat terdidik, dan tentu saja dengan mudah melihat peluang tanpa mempertimbangkan pelanggaran hak intelektual orang lain atau tidak (Wilkie \& Zaickhowsky 1999). Seperti tampak dalam tabel 4 berikut ini, rata-rata tingkat pembajakan software antar Barat dan Timur sebagai berikut: 
Tabel 4

Perbandingan Tingakat Pembajakan Software rata-rata pertahun antara Barat dan Timur tahun 1994-1997

\begin{tabular}{|l|l|c|l|c|}
\hline No & \multicolumn{1}{|c|}{ Barat } & Piracy Rates (\%) & Timur & Piracy Rates (\%) \\
\hline 1 & Australia & 34 & Vietnam & 99 \\
\hline 2 & Austria & 44 & China & 96 \\
\hline 3 & Kanada & 43 & Indonesia & 96 \\
\hline 4 & Denmark & 41 & Oman & 95 \\
\hline 5 & Perancis & 48 & Pakistan & 92 \\
\hline 6 & Jerman & 40 & Pilipina & 90 \\
\hline 7 & New Zealand & 38 & Thailand & 83 \\
\hline 8 & Inggris & 36 & Qatar & 90 \\
\hline 9 & Amerika Serikat & 28 & Turki & 87 \\
\hline
\end{tabular}

Sumber: di cuplik dari Marrron dan Steel 2000

Dengan demikian, tidaklah heran bahwa persoalan mengatasi pembajakan di Asia sangat sulit mencari solusinya dengan dibuktikan bahwa upaya-upaya yang dilakukan pemerintah selalu tidak efektif membendung bisnis ini (Ang et al 2001). Pembajakan terus berlangsung di Asia meskipun sudah disosialisasikannya peraturan hak cipta dengan sangsi berat. Misalnya China, dengan diluncurkannya peraturan untuk memproteksi produk resmi, ternyata pembajakan tidak berkurang secara signifikan, karena strategi membajak juga berubah sesuai dengan perubaahan yang terjadi di bidang hukum pembajakan produk (Birden 1996; dan Wilkie \& Zaickhowsky 1999).

Dalam penelitian yang dilakukan oleh Chang (2003) terbukti bahwa budaya Barat dan Timur menunjukkan perbedaan sangat signifikan dan nampaknya sulit dipertemukan, seperti yang ditunjukkan dalam table 5 berikut ini tentang skala dimensi budaya antara Amerika dan China. Skala dimensi Amerika Serikat (Barat) menunjukkan berbanding terbalik dengan China (Timur) dari keempat aspek yang ada, baik power distance, uncertainty avoidance, individualism dan masculinity. Secara garis besar, perbedaan ini dapat di jabarkan sebagai berikut.

Tabel 5

Perbandinagn antara Budaya USA dan China dalam Hofstede's Cultural Dimensions

\begin{tabular}{|c|c|c|c|c|}
\hline $\begin{array}{c}\text { Bimension } \\
\text { County }\end{array}$ & $\begin{array}{c}\text { Power } \\
\text { Distance }\end{array}$ & $\begin{array}{c}\text { Uncertainty } \\
\text { Avoidance }\end{array}$ & Individualism & Masculinity \\
\hline USA & Low & Low & High & Medium \\
\hline China & High & High & Low & High \\
\hline
\end{tabular}

Sumber: Chang 2003 
Dalam masyarakat China, aktifitas bisnis yang penuh dengan kompetisi, lebih suka dilakukan dengan menggunakan pendekatan "ZeroSum Game". Artinya bahwa masyarakat tipe ini akan selalu menekankan mengalahkan pesaingnya daripada bersaing secara sehat atau kerja sama yang saling menguntungkan. Konsep "Zero Sum Game" ini menekankan pada bagaimana mengambil hak dari lawan pesaingnya tanpa harus mengeluarkan pengorbanan. Namun demikian, karena pengaruh nilai Konghucu terhadap masyarakat china sangat dominan, seperti nilai-nilai kemanusiaan tentang loyalitas, kewajiban timbal balik/saling memberi/saling peduli, berlaku jujur terhadap lainnya (Hill 1994), maka jalan negosiasi masih terbuka untuk mencapai kesepakatan "win-win negotiation" asalnya semua kepentingan kedua belah pihak dapat terpenuhi. Berbeda dengan konsep Barat yang berusaha menekankan pada "win-win solution", saling menghormati hak dan bersaing secara konsekuen (Chang 2003).

Dari hasil penelitian tersebut, maka dapat dikatakan bahwa usaha pembajakan produk tidak lebih dari permainan bisnis yang bersifat "Zero Sum Games" yang memang telah menjadi budaya Timur. Tetapi bukan berarti bahwa semua jalan tertutup untuk mengatasi masalah bisnis haram ini karena masih terbuka peluang negosiasi. Budaya negosiasi perlu menjadi pendekatan oleh pihak Barat untuk mencapai suatu solusi. Barangkali WTO (World Trade Organization) merupakan suatu solusinya. Mungkin.

Dari kajian yang telah dilakukan oleh para ahli, seperti yang telah di paparkan di atas, hubungan antara partisipasi konsumen dengan budaya konsumen terhadap tumbuh suburnya pembajakan produk dapat di skemakan seperti yang telah dilakukan oleh Hidayat \& Phau (2003), sebagai berikut (lihat skema 1). 


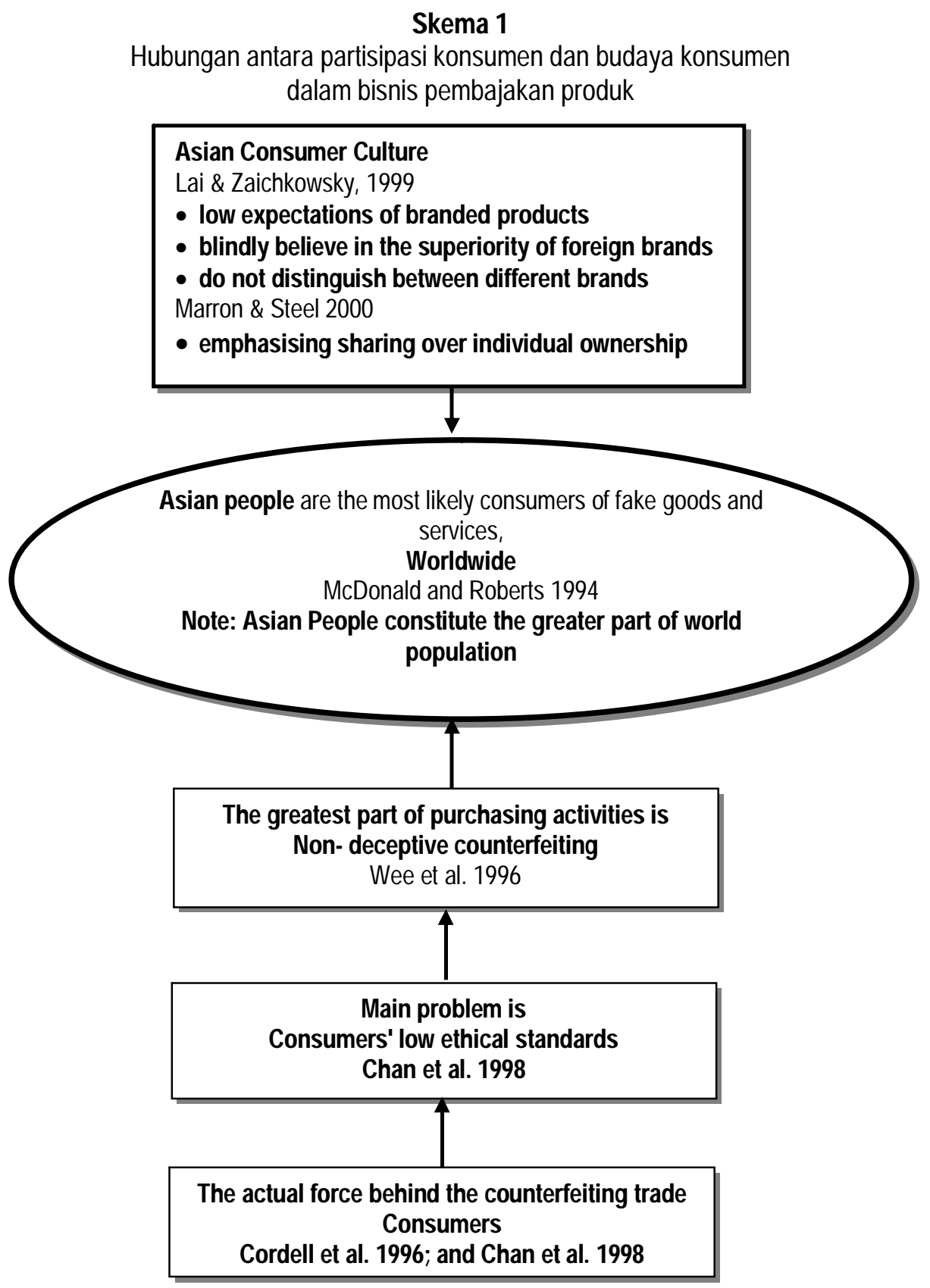

Sumber: Hidayat \& Phau 


\section{PEMBAJAKAN PRODUK DAN UPAYA HUKUM DI INDONESIA}

Era globalisasi yang sarat dengan tehnologi pada kehidupan umat manusia, mendorong penggunaan komputer yang sepertinya sudah merupakan kebutuhan mutlak bagi aktifitas kegiatan masyarakat, terutama masyarakat perkotaan. Usaha bisnis yang menyangkut produk komputer dan perangkat lunaknya menjadi pasar yang menjanjikan bagi pelaku bisnis. Menyimak dari pertumbuhan pasar komputer yang menggelembung dengan cepat memberikan inspirasi pula kepada pelaku bisnis maupun pengguna untuk melakukan tindakan yang illegal, yaitu membajak perangkat keras komputer maupun mengkopi tanpa ijin perangkat lunaknya.

Pada era tahun 1990-an, barangkali penggunaan barang illegal ini terasa nyaman, sehingga berdasarkan data terakhir, Indonesia menduduki peringkat ke tiga Negara pembajak software terbesar dunia setelah Vietnam dan China (Pikiran Rakyat 2002). Menurut Andrie Sibarani, Manager Market Development PT. Microsoft Indonesia, mengatakan bahwa berdasarkan riset dari Business Software Alliance (BSA) kerugian pembajakan di Indonesia rata-rata pertahun sebesar 197 juta dollar US. Secara prosentasi pembajakan software di Indonesia memiliki porsi $97 \%$ dari total software yang beredar di Indonesia (Tiara 205 1998).

Sedangkan produk yang paling banyak di bajak di Indonesia adalah cakram optic, misalnya VCD,DVD,CD dan Audio CD. Angka pembajakan produk cakram optic diperkirakan mencapai $90 \%$ dari seluruh pembajakan di Indonesia, demikian menurut Kombes Pol. Edi Wardoyo, Bereskrim Mabes Polri (Tempo Interaktif 2003). Maka tidaklah mengejutkan kalau MUI pun memandang perlu mengeluarkan fatwa tentang pembajakan produk adalah haram (Coret Moret Amal 2003).

Untuk kasus Indonesia, penyebab tumbuh suburnya pembajakan ini, menurut Cita Citrawinda Priapantja, President Perhimpunan Masyarakat HaKI, adalah sebagai berikut: lemahnya penegakan hukum; lemahnya pemahaman masyarakat terhadap perlindungan hak cipta; dan lemahnya daya beli masyarakat. Kelemahan ini bukan berarti tidak ada upaya yang dilakukan oleh pihak yang berkepentingan. Misalnya, upaya penertiban yang dilakukan oleh ASIREVI bekerjasama dengan pihak berwajib memberikan dampak penurunan penjualan VCD illegal secara berkala, dan Himpunan Masyarakat HaKI Indonesia secara berkala melakukan seminar dengan tema pembrantasan pembajakan dan pemahaman masyarakat kepada HaKI. Upaya ini kurang menunjukkan keberhasilan karena lemahnya sangsi yang berlaku dalam Undang-Undang Nomor 8 Tahun 1992 tentang Hak Cipta (Tiara 205 1998). Apalagi ada beberapa kelompok masyarakat di Indonesia yang memiliki pendapat lain, seperti Jemaah Marabitun dari 
Bandung yang menyebutkan bahwa HaKI adalah konsep kaum kapitalis dan tidak ada tuntunannya dalam hukum Islam (hukum online 1999)

Oleh karena itu, pemerintah RI memandang perlu merivisi UU Hak Cipta dengan mengundangkan UU Hak Cipta No 19 Tahun 2002 dengan sangsi yang lebih keras. Undang-undang baru yang diundur pemberlakuannya selama satu tahun ini juga merupakan konsekuensi dari ratifikasi Konvensi Berne tentang Perlindungan Karya Seni dan sastra dan perjanjian hak cipta world intellectual property organisation. Perlindungan HaKI secara konsekuen juga merupakan prasarat dalam keanggotaan WTO (World Trade Organisation). Namun, tidak dapat dipungkiri bahwa pemberlakukan ini juga merupakan desakan yang kuat dari Negara maju seperti Amerika dan Jepang dengan kemungkinan sangsi perdagangan internasional kalau melakukan pelangaran (Tempo online 2003; dan Pikiran Rakyat 2003).

Keterlibatan Indonesia dengan masalah apresiasi Hak Cipta bukan hal yang baru. Karena dua dasa warsa yang lalu pernah mengundangkannya, yaitu UU No. 6/1982. Setelah itu mengalami revisi dua kali melalui UU No 7/1987 dan UU NO 12/1997. Undang-Undang tentang merek juga telah dimiliki oleh Indonesia melalui UU No 19/1992, dan direvisi lagi dengan UU No. 14/1997. Bahkan undang undang tentang paten juga di miliki oleh Indonesia setelah berlakukanya UU No. 6/1989 dan direvisi kembali dengan UU No. 13/1997 (Bappeda DKI 2001). Dari perjalanan perundangan undang-undang tentang HaKI tersebut, masyarakat Indonesia sebenarnya memiliki atensi yang besar dengan dibuktikannya tindakan revisi yang dilakukan, karena menjadi bukti bahwa masyarakat melihat pekembangan di lapangan, baik kelebihan dan kekurangan dari produk undang-undang tersebut.

Denagan adanya tuntutan global mengenai perdagangan internasional yang semakin transparan terutama terhadap perlindungan hak kekayaan intelektual, dan juga setelah dikaitkan dengan masalah perjanjian dengan lembaga-lembaga internasional, seperti WTO, maka berikut ini adalah bentuk produk hukum terbaru yang berkait dengan Hak Kekayaan Intelektual (lihat tabel 6).

Upaya positip yang dilakukan Indonesia di atas dengan mengundang-kan Hak Kekayaan Intelektual secara lebih lengkap, nampaknya merupakan usaha besar dari Indonesia untuk membangun citra Indonesia kembali di panggung perdagangan Internasional. Namun demikian, kesempurnaan produk hukum yang dimiliki Indonesia tidak akan pernah memiliki arti apapun ketika pemerintah Indonesia tidak mempunyai keseriusan menegakkan hukum tersebut. 
Tabel 6

Produk Hukum mengenai Hak Kekayaan Intelektual Terbaru

\begin{tabular}{|c|c|c|c|}
\hline No. & No. UU & Tentang & Keterangan \\
\hline 1 & 19 Tahun 2002 & Hak Cipta & $\begin{array}{l}\text { Bertujuan melindungi karya kreatif yang dihasilkan } \\
\text { oleh penulis, seniman, pengarang, dan pemain musik, } \\
\text { pengarang sandiwara, serta pembuat film dan piranti } \\
\text { lunak (software) }\end{array}$ \\
\hline 2 & 14 Tahun 2001 & Paten & $\begin{array}{l}\text { Bertujuan melindungi penemu atas hasil penemuannya } \\
\text { di bidang tehnologi atas jangka waktu tertentu }\end{array}$ \\
\hline 3 & 15 Tahun 2001 & Merek & $\begin{array}{l}\text { Bertujuan melindungi pemegang merek yang syah } \\
\text { mengingat merek merupakan pembeda barang atau } \\
\text { jasa miliknya dengan barang atau jasa milik pedagang } \\
\text { lain }\end{array}$ \\
\hline 4 & 29 Tahun 2000 & $\begin{array}{l}\text { Perlindungan } \\
\text { Varietas } \\
\text { Tanaman }\end{array}$ & $\begin{array}{l}\text { Bertujuan melindungi varietas tanaman yang dihasilkan } \\
\text { oleh pemulia tanaman melalui pemuliaan tanaman }\end{array}$ \\
\hline 5 & 30 Tahun 2000 & Rahasia Dagang & $\begin{array}{l}\text { Bertujuan melindungi informasi yang tidak di ketahui } \\
\text { umum di bidang tehnologi ataupun bisnis, dan } \\
\text { informasi tersebut bernilai ekonomi karena berguna } \\
\text { dalam kegiatan usaha. Jangka waktu perlindungan } \\
\text { tidak terbatas. }\end{array}$ \\
\hline 6 & 31 Tahun 2000 & Desain Industri & $\begin{array}{l}\text { Bertujuan melindungi suatu kreasi tentang bentuk, } \\
\text { konfigurasi, atau komposisi garis, atau warna, atau } \\
\text { gabungan semuanya. Desain tersebut memberikan } \\
\text { kesan estetis dan dapat diwujudkan dalam pola tiga } \\
\text { dimensi atau dua dimensi serta dapat dipakai } \\
\text { menghasilkan suatu produk, barang, komoditi industri, } \\
\text { atau kerajingan tangan. }\end{array}$ \\
\hline 7 & 32 Tahun 2000 & $\begin{array}{c}\text { Desain Tata } \\
\text { Letak Sirkuit } \\
\text { Terpadu }\end{array}$ & $\begin{array}{l}\text { Bertujuan melindungi deasian tata letak sirkuit } \\
\text { terpadu. Sirkuit terpadu adalah suatu produk dalam } \\
\text { bentuk jadi atau setengah jadi yang di dalamnya } \\
\text { terdapat berbagai elemen dan sekurang-kurangnya } \\
\text { satu dari elemen tersebut merupakan elemen aktif. } \\
\text { Sebagian atau seluruhnya elemen saling berkaitan, } \\
\text { serta di bentuk secara terpadu di dalam sebuah } \\
\text { bahan semikonduktor untuk menghasilkan fungsi } \\
\text { elektronik. Sedangkan desain tata letak merupakan } \\
\text { kreasi berupa rancangan peletakan tiga dimensi dari } \\
\text { berbagai elemen, sekurang-kurangnya satu dari } \\
\text { elemen tersebut adalah elemen aktif, serta sebagian } \\
\text { atau semua interkoneksi dalam suatu sirkuit terpadu. } \\
\text { Peletakan tiga dimensi dimaksudkan untuk persiapan } \\
\text { pembuatan sirkuit terpadu. }\end{array}$ \\
\hline
\end{tabular}

Sumber : Hukum online 2003 dan Bappeda DKI (online) 2003 


\section{PELUANG PENELITIAN PEMASARAN MENGENAI PEMBAJAKAN PRODUK DI INDONESIA}

Pemasalahan pembajakan produk bukan monopoli Indonesia saja, tetapi juga seluruh dunia. Hal ini mengingat karena bisnis illegal ini berdampak negatip kepada masyarakat maupun pelaku bisnisnya. Oleh karena itu sudah saatnya para ahli Indonesia, terutama yang tertarik dengan bidang pemasaran dapat mejadikan topik pembajakan produk sebagai bidang penelitiannya. Bidang garap penelitian tentang pembajakan produk bisa sangat luas sekali, baik itu dilakukan dalam level konsep, metodologi maupun aplikasinya. Bila dipersempit lagi bidang garap tersebut dapat dipilah menjadi pengkajian sisi permintaan dan pengkajian sisi penjualan/pabrikan.

Pada Sisi permintaan, kajian yang dilakukan terfokus pada perilaku konsumen. Pada perilaku konsumen ini banyak hal yang dapat di kaji. Bidang kajian yang dapat dilakukan, sebagai contoh, adalah karakter konsumen yang dikaitkan dengan keinginan beli mereka terhadap produk bajakan, misalnya: etika konsumen, budaya konsumen, kepatuhan hukum konsumen, dan bisa diperluas lagi dengan mengkaitkan masalah harga beserta persepsi terhadap suatu produk.

Sedangkan pada sisi penjualan, penelitian dapat di fokuskan pada sisi distribusi dengan melihat seberapa jauh distributor memiliki kemauan bekerja sama dengan pabrikan untuk menghambat distribusi produk bajakan. Pada sisi pabrikan pun juga menarik untuk dikaji terutama dalam kaitannya dengan efektifitas strategi pabrikan dalam menghadapi produk bajakan. Seperti diketahui banyak strategi yang telah dilakukan pabrikan, dan berkembang sesuai dengan pertumbuhan produk bajakan yang semakin canggih dilakukan. Misalnya: strategi dengan pembuatan label yang berhologram pada produknya; strategi dengan meningkatkan monitoring ke distributor; strategi dengan menyewa detektif, strategi dengan melakukan tindakan hukum; dan strategi dengan memberi penomoran seri pada produk. Dan suatu hal yang sangat penting adalah kajian di bidang budaya sangat perlu terutama mengetahui akar perilaku bisnis bajakan ini.

Sebagai salah satu contoh konkrit yang mungkin dapat dilakukan dalam kajian pada sisi permintaan, dan nampaknya juga cukup penting untuk dikaji di Indonesia adalah seberapa jauh "kepatuhan hukum konsumen" dan "etika konsumen" mempengaruhi pembelian terhadap produk bajakan. Pada dasarnya kedua konstruk variable ini memiliki implikasi yang berbeda. "Kepatuhan hukum konsumen" berimplikasi pada kepatuhan mentaati hukum yang berlaku, sedangkan "etika konsumen" berimplikasi pada moralitas konsumen dalam memandang suatu tindakan yang berdampak pada nilai-nilai yang dipercaya oleh masyarakat. 
Paling tidak model kajian di atas akan memberikan masukan yang cukup penting bagi pengusaha dalam menyusun strategi usahanya dan bagi pemerintah mendapatkan masukan dalam upaya menyempurnakan peraturan dan kebijakan yang berlaku, terutama yang menyangkut pembajakan produk.

\section{PENUTUP}

Secara hitoris, Perlunya perlindungan terhadap Hak atas Kekayaan Inteklektual (HaKI) nampaknya sudah disadari oleh manusia sejak abad ke 12 yang lalu, yaitu dengan diundangkannya perlindungan atas suatu "penemuan" oleh Raja Inggris pada tahun 1352. Namun demikian, penghargaan terhadap kekayaan intelektual ini bukannya semakin kondusif, tetapi justru semakin merjalelanya pembajakan dilakukan oleh pembajak. Kawasan Asia nampaknya menjadi tertuduh utama sebagai tempat pembajakan produk yang paling besar. Negara "Barat", misalnya Amerika Serikat dan negara-negara Eropa, sebagai pemegang merekmerek dunia, sangat terusik oleh ulah pembajak di kawasan Asia ini. Sehingga tekanan-tekanan ekonomi dilancarkan oleh pihak "Barat" kepada Negara-negara Asia supaya mematuhi hak intelektual dalam bentuk merek dagang.

Akan tetapi, ternyata persoalan pembajakan produk tidak mudah di berantas di Asia. Meskipun jerat hukum yang diperlakukan semakin keras, bahkan dengan ancaman hukumana mati, pembajak semakin canggih mencari strategi untuk menghindari jerat hukum yang berlaku tersebut. Kenyataan ini, pada dasarnya lebih semata-mata karena perbedaan dalam memandang Hak atas Kekayaan Intelektual (HaKI) antara "Barat" dan "Timur". Perbedaan cara pandang ini karena perbedaan budaya antara ke dua kutub tersebut. Budaya "Barat" sangat menjunjung hak individu, sedangkan budaya "Timur" menekankan pada "sharing" di atas kepentingan individu. Cara pandang yang berbeda, individualism versus collectivism, menimbulkan benturan dalam upaya mempersempit ruang gerak pembajakan antara Negara Barat dengan Negara Timur.

Indonesia sebagai bagaian dari Negara yang berbudaya "Timur" menghadapi kesulitan dalam membrantas pembajakan ini. Hingga akhir abad ini, Indonesia masih menduduki peringkat Negara-negara papan atas yang melakukan pembajakan. Tetapi bukan berarti Indonesia tidak memiliki produk hukum yang baik dalam menangkal pembajakan tersebut. Indonesia bahkan telah meluncurkan produk-produk hukum terbaru yang disesuaikan dengan definisi World Trade Organisation (Direktoral Jenderal HKI $\mathrm{RI})$. Meskipun di akui juga bahwa produk hukum tersebut karena ada desakan oleh Negara maju, misalnya Amerika Serikat dan Jepang, yang dikait- 
kan dengan perdagangan internasional. Persoalan yang dihadapi saat ini adalah seberapa besar kemauan penegak hukum Indonesia dalam menegakkan peraturan tersebut. Ada perangkat Hukum tetapi tidak memiliki kemamuan menegakkannya maka persoalan pembajakan tidak akan pernah tertuntaskan. Apalagi kita sadari bahwa dari sudut budaya, pemberlakuan HaKI masih belum mendapatkan persepsi yang sama di masyarakat.

\section{REFERENSI}

Abalos, R. J. (1985), 'Commercial Trademark Counterfeiting in he United States, the Third World and Beyond: American and International Attempts to Stem the Tide,' Boston College Third World Law Journal,vol. 5, pp. 151-178.

Ang, S. H., Cheng, P. S., Lim, E. A. C. \& Tambyah, S. K. 2001, 'Spot the difference: consumer responses towards counterfeits,' Journal of Consumer Marketing, vol. 18, no. 3, pp. 219-235.

Bamossy, G. \& Scammon, D. L. 1985, 'Product Counterfeiting: Consumers and Manufacturing Beware,' Advances in Consumer Research, vol. 12, Hirshmen, E. C. \& Holbrook, M. B. (eds), Association for Consumer Research, pp. 334-339.

Bappeda DKI,'Info HaKI: HaKI dalam Perundangan Kita (online),' 17 September 2003, sumber: http://www.bappedajakarta.go.id/ kilas/haki.html.

Benghozi, P. J. \& Santagata, W. 1998,'Market Piracy in the Design-based Industry: Economics and Policy Regulation,' Working Paper was presented at the International Seminar, "The Economics of Copying and Counterfeiting", ICARE, December 3-4, Venice, pp. 1-24.

Birden, P. B. Jr. 1996,'Trademark Protection in China: Trends and Directions,' Loyola of Los Angeles International and Competitive Law Journal, vol. 18, no. 3, pp. 431-495.

Bloch, P. H., Bush, R. F. \& Campbell, L. 1993, 'Consumer Accomplices in Product Counterfeiting, A Demand Side Investigation,' Journal of Consumer Marketing, vol. 10, no. 4, pp. 27-36.

Bush, R. F., Bloch, P. H. \& Dawson, S. 1989, 'Remedies for Product Counterfeiting,' Business Horizon, January-February, pp. 59-65.

Business Week,'The 100 Top Brands,' Agustus 4th 2003 , pp. 72-78. 
Chan, A., Wong, S. \& Leung, P. 1998, 'Ethical beliefs of Chinese consumers in Hong Kong,' Journal of Business Ethics, vol.17, no. 11, pp. 1163-1170.

Chakraborty, G., Alfred, A. T., and Bristol, T. 1996, 'Exploring Consumers' Evaluations of Counterfeits: The Roles of Country of Origin and Ethnocentrism' in Advances in Consumer Research, vol. 23, pp. 379-384.

Chaudhry, P. E. and Walsh, M. G. 1996, 'An assessment of the impact of counterfeiting in international markets: The Piracy Paradox Persists,' The Columbia Journal of World Business, Fall, pp. 34-48.

Chaudhry, P. E. \& Walsh, M. G. 1995,'Intellectual Property Rights. Changing Levels of Protection Under GATT, NAFTA and the EU,' The Columbia Journal of World Business, Summer, pp. 81-92.

Chang, L. C. 2003,' An Examination of Cross-Cultural Negotiation: Using Hofstede Framework,' The Journal of American Academy of Business, vol. 2, no. 2, pp. 567- 570.

Cordell, V. V., Wongtada, N. \& Kieschnik, Jr., R. L. 1996, 'Counterfeit Purchase Intentions: Role of Lawfulness Attitudes and Product Traits as Determinants,' Journal of Business Research, vol. 35, pp. 41-53.

Coriat, B. \& Orsi, F. 2002,' Establishing a new intellectual property rights regime in the United States. Origin, content and problems,' Research Policy, vol. 31, pp. 1491-1507.

Coret Moret Amal,' Fatwa Produk Rekaman Bajakan,' 19 Februari 2003, sumber:http://coretmoret.web.id/ archives/2003/02/fatwa_produk_rekaman_bajakan.

Crandall, C. 1986,'The Cost of Counterfeit Products,' Consumer Research, May, pp.33-35.

d'Astous, A. \& Gargouri, E. 2001, 'Consumer evaluations of brand imitations,' European Journal of Marketing, vol. 35, no. 1/2, pp. 153-167.

Delener,N. 2000, 'International Counterfeit Marketing: Success Without Risk,' Review of Business, spring, pp. 16-20.

Dirjen. HKI RI,'Recognition of Intellectual Property Rights in Indonesia,' 26 November 2003, sumber: http://www.dgip.go.id/ english/pengantar.htm. 
Dodd, C. C. \& Zaichkowsky, J. L. 1999,'National Brand Responses to Brand Imitation; Retailers versus Other Manufacturers,' Journal of Product and Brand Management, vol. 8, no. 2, pp. 96-105.

East Asian Executive Reports,'Regional; United States: Intellectual Property Protection: 1998 USTR special 301 decisions, March 15 ${ }^{\text {th }}$ 1998, Washington.

Ewing, M. T., Napoli J., Caruana, A. 2000,' Asian Networks: An Individualist-Collectivist Perspective,' the Journal of Contemporary Issues in Business and Governance, vol. 6, no. 2, pp. 25-32.

Fereshti N. D. 2003,' Pelaku Pembajakan vs Konsumsi Produk Bajakan,'Pikiran Rakyat, 16 Juli, sumber: http://www.pikiranrakyat.com/cetak/0703/0804.htm

Field, J. R. B. 2000,'An Empirical Investigation of Consumers' Perceptions and Purchase Intentions of Counterfeit Products: A Means-End Chain Analysis,' A PhD Dissertation, Mississippi State University, available: http://wwwwlib.umi.com/dissertations/previewall/ 9991310.

Forestor, T. \& Morrison, P. 1990,Computer Ethics: Cautionary Tales and Ethical Dilemmas in Computing, MIT Press, Cambridge.

Gabella, G. \& Picasso, M. D. 1995,' PC Software Industry Lost $\$ 8.08$ Billion To Pirates In 1994. Piracy Rate in the US Declines,' Information \& Management, vol. 29, pp. 285-288.

Ganguli, P. 2000, 'Intellectual Property Rights. Imperative for the knowledge industry,' World Patent Information, vol. 22, pp. 167-175.

Glass, A. J. \& Saggi, K. 2002,'Intellectual property rights and foreign direct investment,' Journal of International Economics, vol. 56, pp. 387-410.

Globerman, S. 1988,'Addessing International Product Piracy,' Journal of International Business Studies, Fall, pp. 497-504.

Grossman, G. M. \& Shapiro, C. 1988,'Foreign Counterfeiting of Status Goods,' The Quarterly Journal of Economics, February, 79-100.

Harvey, M. 1988, 'A New Way to Combat Product Counterfeiting,' Business Horizon, Jul-Aug, pp. 19-28.

Harvey, M. G. \& Ronkainen, I. A. 1985,'International Counterfeiters: Marketing Success Without the Cost or The Risk,' Columbia Journal of World Business, vol. 20, Fall, pp. 37-45. 
Harvey, P. J. \& Walls, W. D. 2003,' The Revealed Demand for Pirate Goods: Profit Analysis of Experimental Data,' International Journal of Management, vol. 20, no. 2, pp. 194-201.

Harvey, M. G. \& Lucas, L. A. 1996,'Intellectual Property Rights Protection: What MNC Managers Should Know About GATT?' Multinational Business Review, vol. 4, pp. 77-93.

Hidayat \& Phau 2003a,' Product Counterfeiting: The "New Worldwide Real Product" Without Business Risks. A Proposed Study of the Demand and Supply sides Investigations,' World Marketing Congress Proceeding, June $11^{\text {th }}-14^{\text {th }}$, Perth.

Hidayat \& Phau 2003b,' A Review of Product Piracy: The Emergence of "New Real" Business without Boundaries and Risks,'Working Paper Series, CBS Curtin Technology of University (forthcoming).

Hill, C. W. L. 1994, International Business: Competing in the Global Marketplace, Irwin Publisher, Burr Ridge, Illinois.

Hofstede, G. H. 1980,'Culture's Consecuences, International Differences in Work Related Values,' Sage Publication, Beverly Hills.

Hofstede, G. H. 1997, Cultures and Organizations: Software of the mind, McGraw Hill, New York.

Hukum online 1999,' Mengkaji Hak Kekayaan Intelektual dari Kacamata Hukum Islam, 30 Desember 1999, sumber: http://hukumonline.com/ print.asp?id=9324\&cl=berita

Husted B. W. 2000,' The impact of national culture on software piracy,' Journal of Business Ethics, vol. 26, pp. 197-211.

International AntiCounterfeiting Coalition 2002,'Get the Facts on Fakes! The Economic Impact of Product Counterfeiting,' available: http: /lwww.iacc.org/ economic.html.

Jawa Pos,' UU Hak Cipta Diberlakukan,' 30 Juli 2003, sumber: http:/ Isearch.jawapos. com / index.php? act= detail_s\&id=54947.

Johnson, J. M. 2001/2002,'Solving China's counterfeiting problem, Managing Intellectual Property, no. 15, 4.

Kau, A. K., Rinnie, H. \& Swinyard, W. R. 1990, 'The Morality of Software Piracy: A Cross Cultural Analysis,' Journal of Business Ethics, vol. 9, no. 8, pp. 655-664.

Koen, C. M. \& Im, J. H. 1997,'Applications: Software piracy and its legal implications,' Information \& management, vol. 31, pp. 265-272. 
Koran Tempo,'Hak Cipta dan Hak Bajak,' 7 Agustus 2003, sumber: http://www.korantempo.com/korantempo/news/2003/8/7/opini/100. $\mathrm{html}$.

Lantu , S. \& Farida, I. 2003,' 213 Tahun, dari Paten Menuju Hak Cipta,' Pikiran Rakyat, 26 September, sumber: http://www.pikiranrakyat.com/ cetak/0803/12/ 0811.htm.

Lai, K. K. Y. \& Zaichkowsky, J. L. 1999,'Brand Imitation: Do the Chinese have different views?' Asia Pacific Journal of Management, vol. 16, pp. 179-192.

Lai, E. L. C. \& Qiu, L. D. 2003,' The North's intellectual property rights standard for the South?' Journal of International Economics, vol. 59, pp. 183-209.

Lehman, B. A. 1997,'Intellectual Property: America's Competitive Advantage in the 21th Century,'Columbia Journal of World Business, vol. 31, pp. 6-16.

Lynch, S. 2002,'Commercial Counterfeiting,' Paper prepared for Trade Inspections Conference, October 23, pp. 1-23.

McDonald, G. M. \& Roberts, C. 1994, 'Brand piracy, The Problem that Will not Go Away,'Journal of Product and Brand Management, vol. 3, no. 4, pp. 55-65.

Marron, D. B. \& Steel D. G. 2000,' Which countries intellectual property? The case of software piracy,' Economic Inquiry, vol. 38, no. 2, pp. 159-174.

Mitchell, V.W. \& Papavassiliou, V. 1997,' Exploring consumer confusion in the watch market,' Marketing Intelligence and Planning, vol. 15, no. 4, pp. 164-172.

Miller, N. D. L. 1999,'Consumer misbehaviour: Why people buy illicit goods,' Journal of Consumer Marketing, vol. 16, no. 3, pp. 273-287.

Nash, T. 1989, 'Only Imitation? The rising cost of counterfeiting,' Director, May, pp. 64-69.

Nia, A. \& Zaichkowsky, J. L. 2000, 'Do Counterfeits devalue the ownership of luxury goods?' Journal of Product and Brand Management, vol. 9, no. 7, pp. 485-497.

Nimmer, D. 1992,'Nation, Duration, Violation, Harmonization: An International Copyright Proposal for the United States,' Law and Contemporary Problems, vol. 55, pp. 211-239. 
Olsen, J. E. \&Granzin, K. L. 1992, 'Gaining Retailers' Assistance in Fighting Counterfeiting: Conceptualization and Empirical Test of a Helping Model,' Journal of Retailing, vol. 68, Spring, pp. 90-111.

Paradise, P. R. 1999, Trademark Counterfeiting, Product Piracy, and the Billion Dollar Threat to the US Economy, Quorum Books, London.

Paula, S. 1986,'Foreign Product Counterfeiting,' Vital Speeches of the Day, April 14, pp. 2-6.

Pinkerton, L. F. 1990,'Due Diligence in fine art transactions,' Case Western reserve Journal of International Law, vol. 22, Winter, pp. 1-29.

Pikiran Rakyat, 'Selisih Harga antara Lisensi dengan Bajakan Tinggi. Indonesia Peringkat III Pembajakan "Software", 09 Agustus 2002, sumber: http://www.pikiran-rakyat.com/cetak/0802/09/0302.htm.

Pikiran Rakyat,'UU Hak Cipta tak Rugikan Masyarakat,' 10 Agustus 2003, sumber: http://www.pikiran-rakyat.com/cetak/0803/10/0702.htm.

Phau, I. \& Prendesgast, G. 1998,'Custom Made Fakes: A Mutant Strain of Counterfeit Products,'Proceedings of Globalization of Business Conference, $16^{\text {th }}-18^{\text {th }}$ November, Cyprus

Phau, I., Prendergast, G. \& Chuen, L. H. 2000,'Profiling brand-piracy-prone consumers: An exploratory study in Hongkong's clothing industry,' Journal of Fashion Marketing and Management, vol. 5, no. 1, pp. 45-55.

Rapp, R. T. \& Rozek, R. P. 1990,' Benefit and Cost of Intellectual Property Protection in Developing Countries,' Journal of World Trade, vol. 24, no. 5, pp. 75-102.

Seyoum, B. 1996,' The Impact of Intellectual Properti Rights on Foreign Direct Investment,' Columbia Journal of World Business, vol. 31, pp. 50-59.

Simone, J. T. 1999,'Countering Counterfeits,' The China Business Review, Jan-Feb, pp. 12-19.

Shore, B., Venkatachalam, A. R., Solorzano, E., Burn, J. M., Hassan, S. Z. \& Janczewski, L. J.. 2001, 'Softlifting and piracy: behaviour across cultures,' Technology in Society, vol. 23, pp. 563-581.

Shultz, C. \& Saporito, B. 1996,'Protecting Intellectual Property: Strategies and Recommendations to Deter Counterfeiting and Brand Piracy in Global Market,' Columbia Journal of World Business, Spring, pp. 18-28. 
Shkodriani, G. M. \& Gibbons, J. L. 1995,' Individualism and Collectivism Among University Students in Mexico and United States, The Journal of Social Psychology, vol. 135, no. 6, pp. 765-772.

Steidlmeier, P. 1993,'The Moral Legitimacy of Intellectual Property Claims: American Business and Developing Country Perspectives,' Journal of Business Ethics, vol. 12, no. 2, pp. 157-164.

Stoland, E. 1977,'White Collar Criminals,' Journal of Social Issues, vol. 33, pp. 179-196.

Tempo interaktif,' Pembajakan Terbesar di Indonesia Terjadi Pada Cakram Optik,' 22 Oktober 2003, sumber:

http://www.tempo.co.id/hg/ekbis/2003/10/22/brk, 20031022-68,id.html

Triandis, H. C. 1995, Individualism and Collectivism, Westview Press, Boulder, Co.

Tiara 205,' CD, VCD \& CD-ROM Bajakan,'Mei 1998, sumber: http://www. vision.net.id / tiara/205/ realita .html.

Wada, T. 1996,'Brand -name demand brings more fakes. Smuggler improve quality and tactics, confound afficials,' Nikkei Weekly, vol. 34, no. 1, available: http://satellite.Nikkei.co.jp/news/TNW/back/42TNWCOVER3.html.

Wee, C. H., Tan, S. J. \& Cheok, K. H. 1996, 'Non-price determinants of intention to purchase counterfeit goods,' International Marketing Review, vol. 12, no. 6, pp. 13-46.

Wilkie, R. \& Zaichkowsky, J. L. 1999, 'Brand Imitation and its Effects on Innovation, Competition, and Brand Equity,' Business Horizon, Nov-Dec.

Wijk, J. V. 2002,'Dealing with Piracy: Intellectual Asset Management in Music and Software,' European Management Journal, vol. 20, no. 6, pp. 689-698. 